\title{
Thermal inactivation of polyphenoloxidase and peroxidase in Jubileu clingstone peach and yeast isolated from its spoiled puree
} Andréa Menezes LOPES $^{1 *}$, Ricardo Peraça TORALLES ${ }^{2}$, César Valmor ROMBALDI ${ }^{3}$

\begin{abstract}
The thermal inactivation of yeast isolated from spoiled Jubileu peach puree and that of polyphenoloxidase (PPO) and peroxidase (POD) in cv. Jubileu, which is widely cultivated in southern Rio Grande do Sul state, Brazil, were studied. PPO and POD were extracted using the protein powder method and submitted to partial purification by precipitation followed by dialysis. The enzymatic activity was determined measuring the increase in absorbance at $420 \mathrm{~nm}$ for PPO and $470 \mathrm{~nm}$ for POD. The yeast used in this investigation was isolated from spoiled Jubileu peach puree at $22^{\circ} \mathrm{Brix}$, with total initial microbial count of $22 \times$ $10^{2} \mathrm{UFCmL}^{-1}$. Stock cultures were maintained on potato dextrose agar (PDA) slants at $4{ }^{\circ} \mathrm{C}$ and $\mathrm{pH} 5$ for later use for microbial growth. In all cases, kinetic analysis of the results suggests that the thermal inactivation was well described by a first-order kinetic model, and the temperature dependence was significantly represented by the Arrhenius law. Both enzymes were affected by heat denaturation, and PPO was more thermostable. PPO was also more thermostable than the yeast isolated from peach puree. The D60-values were 1.53 and $1.87 \mathrm{~min}$ for PPO and yeast isolated from spoiled Jubileu peach puree, respectively.
\end{abstract}

Keywords: peach puree; heat resistance; yeast; enzymatic browning, blanching.

\section{Introduction}

The natural color and taste of fruits are important attributes for the consumer's choice (Toralles et al., 2006). Preserving them in minimally processed fruits, purees, nectars, and juices is a big challenge (Guerrero-Beltrán et al., 2004; McLellan \& Padilla-Zakour, 2005; Quevedo et al., 2011).

Polyphenoloxidase (PPO) and peroxidase (POD) are enzymes associated with oxidative deterioration reactions that can cause browning of these products when not properly controlled (Brito et al., 2005; Toralles et al., 2010). Besides the color change, enzymatic browning can induce severe changes in flavor and texture and cause nutritional losses (Valderrama \& Clemente, 2004; Garcia \& Barrett, 2005; Prohens et al., 2007; Bi et al., 2013).

Polyphenoloxidases catalyze the oxidation of phenolic substrates using oxygen as a hydrogen acceptor in two different types of reactions. PPO (EC 1.14.18.1, monophenol, L-dopa: oxygen oxidoreductase) is involved in the hydroxylation of monophenols in order to originate o-diphenols and PPO (EC 1.10.3.1, 1,2-benzenodiol: oxygen oxidoreductase), which catalyzes the removal of hydrogen from o-diphenols to produce an o-quinonone (Ramírez et al., 2003).

Peroxidase catalyzes four types of reactions: peroxidatic, oxidatic, catalatic, and hydroxylation. For phenolic substrates, only the peroxidatic reaction is important. In this case, POD (EC 1.11.1.7., $\mathrm{H}_{2} \mathrm{O}_{2}$ donor, oxidoreductase) catalyzes the reaction of hydrogen peroxide or other organic peroxide, which is reduced, whereas an electron donor $\left(\mathrm{AH}_{2}\right)$ is oxidized. The electron donor may be ascorbate, phenols, amines, or other organic compounds (Brito et al., 2005). In many cases, the oxidation product is colorful and serves as the basis for the colorimetric determination of peroxidase activity. On the other hand, the oxidative reaction can occur in the absence of hydrogen peroxide; however, it requires the presence of oxygen and cofactors (manganese and phenol). Hydroquinone, dihydroxyfumaric acid, and ascorbic acid are the possible substrates to be treated in this type of reaction (Pinto, 2008). Furthermore, the enzyme action aims primarily to control the level of peroxides generated in almost all cellular compartments and, in the absence of a hydrogen donor, peroxidase converts hydrogen peroxide into $\mathrm{H}_{2} \mathrm{O}$ and $\mathrm{O}_{2}$. This catalatic reaction is at least a thousand times slower than peroxidation (Pinto, 2008; Ranieri et al., 2001).

In peaches, the activity of PPO and POD has long been known and has still been widely studied (Reyes \& Luh, 1960; Flurkey \& Jen, 1978; Alba et al., 1996; Girner et al., 2002). For Brazilian cultivars, although thermal inactivation of PPO and POD in Granada clingstone peaches (Toralles et al., 2005) and even the potential for enzymatic browning of some Brazilian peach cultivars (Toralles et al., 2004) are known, there is very little literature pertaining to the thermal inactivation of other peach cultivars. Knowing such inactivation kinetics is very important because, traditionally, the control of enzymatic browning in fruit juices and purees results from the combination of heat treatment and chemical inhibitors (McEvily et al., 1992; Funamoto et al., 2003; Toralles et al., 2010).

On the other hand, knowing the types of microorganisms present in purees, as well as their thermal resistance, is of

${ }^{1}$ Escola de Química e Alimentos, Universidade do Rio Grande - FURG, Rio Grande, RS, Brasil, e-mail: andrealopes@furg.br

${ }^{2}$ Laboratório de Bioquímica, Departamento de Química, Instituto Federal Sul Riograndense - IFSUL, Pelotas, RS, Brasil

${ }^{3}$ Departamento de Ciência e Tecnologia Agroindustrial, Faculdade de Agronomia Eliseu Maciel, Campus Universitário, Universidade Federal de Pelotas - UFPEL, Pelotas, RS, Brasil ${ }^{*}$ Corresponding author 
fundamental importance to produce a microbiologically stable product. More than 160 types of microorganisms have already been identified at different stages of peach puree processing, particularly the species Bacillus badius, Penicillium sp., and Saccharomyces cerevisiae (Garza et al., 1994a). The last one, when not properly inactivated during pasteurization, may cause fermentation of the peach puree basically in two key steps: the transformation of sugar into pyruvate and of pyruvate into ethanol (Guerrero-Beltrán \& Barbosa-Cánovas, 2006; Fazio, 2006). However, no report was found on the use of thermal treatment to inactivate yeasts isolated from peach puree obtained from a Brazilian cultivar.

The present research studied the thermal inactivation of PPO, POD, and yeasts in cv. Jubilee peach with the objective of defining an indicator for thermal inactivation. The parameters selected were: inactivation rate constant (k), activation energy $\left(E_{a}\right)$, half-life time $\left(t_{1 / 2}\right)$, reduction time $(D)$, and value $(\mathrm{Z})$. Cultivar Jubilee was chosen due to its low potential for browning and its sensory attributes that are favorable for the elaboration of puree, nectars, and juices (Toralles et al., 2006).

\section{Materials and methods}

\subsection{Peach puree}

Ripe and sound-appearing clingstone cv. Jubileu peaches were picked from a commercial orchard in Pelotas/RS, Brazil, and stored at $1-3^{\circ} \mathrm{C}$ for two days at most during the experiment. Jubileu peach puree was obtained directly in plants of the Food Technology Department of IFSUL - Pelotas, using the methodology described by Toralles \& Vendrusculo (2007). Following the process proposed by these authors for Granada peach puree, the peaches were initially peeled, pitted, and blanched at $75^{\circ} \mathrm{C}$ for 4 minutes. Later, the blanched pulp was refined to a $1 \mathrm{~mm}$ particle size to form the peach puree. The puree was stored in a stainless steel tank for the addition of $0.08 \%(\mathrm{w} / \mathrm{w})$ ascorbic acid and then immediately centrifuged in a continuous separator (Westfallen - Germany KO 2006) at $8,380 \mathrm{rpm}$. A conventional homogenizer (Kirchfeld - Germany $\mathrm{HL}$ ) was used to homogenize the centrifuged peach puree under a high pressure of 100 bar. After that, those authors recommend concentrating the homogenized peach puree by vacuum evaporation using a falling-film evaporator (Wiegand - Germany) in order to reach $32^{\circ} \mathrm{Brix}$. In the current study, for technical reasons, the peach puree was concentrated at $22^{\circ}$ Brix. Finally, the thermal treatment of puree was carried out in completely filled and hermetically sealed glass flasks 9 $\mathrm{cm}$ in diameter and $10 \mathrm{~cm}$ tall, which were then submerged in a water bath at $100^{\circ} \mathrm{C}$ for 15 minutes. Three sample flasks were placed in a circulator bath at $1.7^{\circ} \mathrm{C}$ and stored at $-20^{\circ} \mathrm{C}$ for six years. The experiments were performed three times by analyzing the parameters, and also the physical and chemical analyses of the peach puree were determined by the second methodology of the Institute Adolfo Lutz (2008).

\subsection{Microorganisms and microbial growth}

The microorganisms used throughout this investigation were isolated from spoiled Jubileu peach puree at $22^{\circ} \mathrm{Bix}$ and counted as described by Siqueira (1995). The total initial microbial count, $22 \times 10^{2}$ UFC. $\mathrm{mL}^{-1}$, was taken after 5 days of storage at $25^{\circ} \mathrm{C}$ using potato dextrose agar plates. Stock cultures were maintained on potato dextrose agar (PDA) slants at $4{ }^{\circ} \mathrm{C}$ and $\mathrm{pH}$ 5. At this $\mathrm{pH}$, the growth of yeasts in detriment of mold was observed. The yeasts were grown in shaken Erlenmeyer flasks $(150 \mathrm{rpm})$ at $30^{\circ} \mathrm{C}$ for $24 \mathrm{~h}$ in a culture medium (pH 5) with the following composition: yeast BDA $\left(20\right.$ g. $\left.\mathrm{L}^{-1}\right)$; glucose $\left(20\right.$ g. $\left.\mathrm{L}^{-1}\right) ;\left(\mathrm{NH}_{4}\right)_{2} \mathrm{SO}_{4}\left(1\right.$ g.L. $\left.\mathrm{L}^{-1}\right) ; \mathrm{KH}_{2} \mathrm{PO}_{4}\left(2\right.$ g. $\left.\mathrm{L}^{-1}\right) ; \mathrm{MgSO}_{4} \cdot 7 \mathrm{H}_{2} 0$ $\left(0.5\right.$ g.L $\left.\mathrm{L}^{-1}\right) ; \mathrm{FeSO}_{4}\left(0.5\right.$ g.L $\left.\mathrm{L}^{-1}\right)$, and peptone $\left(5\right.$ g.L $\left.\mathrm{L}^{-1}\right)$. Next, a new culture was carried out to purify the yeasts. The suspensions were counted to obtain a concentration of about at $10^{8}$ yeast cells per milliliter and stored at about $4{ }^{\circ} \mathrm{C}$ until analysis.

\subsection{Heat treatments and microbial count}

Heat resistance was determined using a heated bath circulator (Marconi, Piracicaba, Brazil). Aliquots $(4 \mathrm{~mL})$ of the yeast suspension, which were isolated, using the procedure previously described in section 2.2 , centrifuged at $3,500 \mathrm{rpm}$, and heated in sealed glass tubes $(9 \mathrm{~mm}$ i.d., $1 \mathrm{~mm}$ wall $)$ at different temperatures $\left(55\right.$ to $65^{\circ} \mathrm{C}$ ) for different periods of time. After heating, the samples were cooled in an ice water bath. The menstruum ( $4 \mathrm{~mL}$ of glucose at $10 \% \mathrm{~m} / \mathrm{v}$ ) was then inoculated with $4 \mathrm{ml}$ of the yeast suspension under constant agitation (1,500-2,000 rpm). The concentration of the final mixture for fermentation was $278 \mathrm{mM}$ of glucose. This was conducted at $\mathrm{pH} 5$ and appropriate temperature. After 1 hour of fermentation, $1 \mathrm{~mL}$ samples were then removed at intervals, transferred to tubes containing $9 \mathrm{~mL}$ of diluents, and the total microbial count was performed by the pour plate technique after storage for 5 days at $25^{\circ} \mathrm{C}$.

\subsection{PPO and POD Assay}

The polyphenoloxidase (PPO) and peroxidase (POD) enzymes were extracted from cv. Jubileu clingstone peaches using the acetone powder method, partially purified by $\left(\mathrm{NH}_{4}\right) \mathrm{SO}_{4}$ precipitation and dialysis as described by Toralles et al. (2005).

PPO activity was determined by measuring the increase in absorbance at $420 \mathrm{~nm}$ using a Varian Cary 100 UV-VIS spectrophotometer. The PPO reacting mixture contained $4.5 \mathrm{~mL}$ of catechol substrate in the homogenization buffer $(100 \mathrm{mM}$ citrate- $200 \mathrm{mM}$ phosphate buffer) and $0.5 \mathrm{~mL}$ of enzymatic extract. In the final reaction mixture, the concentration was 27.3 $\mathrm{mM}$ of catechol. The reaction was conducted at $\mathrm{pH} 6.2$ and $30^{\circ} \mathrm{C}$.

The spectrophotometric method was also used to measure POD activity at $470 \mathrm{~nm}$. Guaiacol, in the presence of hydrogen peroxide, was used as the substrate instead of catechol. The POD reaction mixture contained $4.5 \mathrm{~mL}$ of guaiacol: $\mathrm{H}_{2} \mathrm{O}_{2}$ in the homogenization buffer and $0.5 \mathrm{~mL}$ of the enzyme. In the final reaction mixture, the concentration was $25.8 \mathrm{mM}$ of guaiacol: $\mathrm{H}_{2} \mathrm{O}_{2}$. The reaction was conducted at $\mathrm{pH} 5.0$ and $30^{\circ} \mathrm{C}$. An aliquot of $0.5 \mathrm{~mL}$ of homogenization buffer was used as blank control for both enzymes. Enzyme activity was calculated based on the linear portion of the curve. One unit of enzymatic activity was defined as the amount that causes an increase of 0.01 unit of absorbance per minute and per milliliter of dialyzed enzyme extract. Protein was determined by the method of Lowry et al. (1951) using BSA as standard (Acros, New Jersey, USA); the protein content of the dialyzed enzyme extract was $400 \mu \mathrm{g} \cdot \mathrm{mL}^{-1}$. 


\subsection{Heat treatments of PPO and POD}

Heat resistance was determined using a heated bath circulator (Marconi, Piracicaba, Brazil). Aliquots $(0.5 \mathrm{~mL})$ of the enzyme solution $(400 \mu \mathrm{g} / \mathrm{mL})$ in the homogenization buffer were heated in sealed glass tubes ( $9 \mathrm{~mm}$ i.d., $1 \mathrm{~mm}$ wall) at different temperatures $\left(40\right.$ to $90{ }^{\circ} \mathrm{C}$ ) for different periods of time. After heating, the samples were cooled in an ice water bath, and the remaining activity was measured using the procedure previously described.

\subsection{Modeling}

The first-order rate constants $(\mathrm{k})$, microbial reduction, or enzyme denaturation were determined using the slopes of the denaturation time courses, according to Equation 1

$\log \left(\frac{A_{t}}{A_{o}}\right)=-(k / 2.303) t \quad$ or $\ln \left(\frac{A_{t}}{A_{o}}\right)=-k t$

where $A_{0}$ is the initial microbial load $\left(N_{o}=U F C \cdot \mathrm{mL}^{-1}\right)$ or initial enzyme activity (in $\mathrm{U}_{\mathrm{min}}{ }^{-1} \cdot \mathrm{mL}^{-1}$ ), and $\mathrm{A}$ is the residual microbial or activity after heating for the specified time. The slopes of these lines were determined by linear regression and the calculated rate constants were replotted in Arrhenius plots. Activation energies (Ea) were calculated from the slopes of the Arrhenius plots of $\ln (\mathrm{k})$ versus $1 / \mathrm{T}$ according to Equation 2

$\ln (\mathrm{k})=-\mathrm{Ea} / \mathrm{RT}+\ln \mathrm{A}$

where $\mathrm{R}$ is the gas constant ( $8.314 \mathrm{~J} . \mathrm{mol} . \mathrm{K}$ ), $\mathrm{T}$ is the temperature in $\mathrm{K}$, and $\mathrm{A}$ is called the pre-exponential factor. Slopes were calculated by linear regression.

A useful indication of the rate of a first-order chemical reaction is the half-life $t_{1 / 2}$ of a substance, i.e., the time it takes for its concentration to fall to half of its initial value. The time for $[A]$ to decrease from $[A]_{0}$ to $1 / 2[A]_{0}$ in a first-order reaction is given by Equation 1 as

$$
\text { k.t } \frac{1}{2}=-\ln \left(\frac{\frac{1}{2} A_{o}}{A_{o}}\right)=-\ln (1 / 2)=\ln 2
$$

Hence

$$
t_{\frac{1}{2}}=\frac{\ln 2}{k}
$$

The main point to observe about this result is that, for a first-order reaction, the half-life of a reactant does not depend on its initial concentration.

\subsection{Decimal reduction time (D-value)}

$\mathrm{D}$-value is the time required at a certain temperature to inactivate $90 \%$ of microorganisms or enzyme activity and is given by Equation 4:

$D=\frac{2.303}{k}$ where $D$ (minutes or seconds) is the decimal reduction time, and $k$ is the inactivation constant rate $\left(\mathrm{s}^{-1}\right)$.

\subsection{Z-value}

The Z-value indicates the number of degrees the temperature must be increased to decrease the microbial population by one $\log$ cycle and measure the microbial heat resistance, calculated as follows:

$\log D=-m T$

where $m$ is the slope $\left({ }^{\circ} \mathrm{C}^{-1}\right)$, T is temperature $\left({ }^{\circ} \mathrm{C}\right)$, and $\mathrm{Z}\left({ }^{\circ} \mathrm{C}\right)$ is computed from the negative inverse of the slope.

\section{Results and discussion}

\subsection{Physical and chemical characteristics}

Table 1 shows the physical and chemical characterization of the Jubileu peach puree after reaching concentration of $22^{\circ} \mathrm{Brix}$. In general, the physical and chemical values are not commonly reported for peach puree concentrate at $22^{\circ} \mathrm{Brix}$. Nevertheless, some associations are possible because peach puree is evaluated in single strength form or concentrated at $30-32^{\circ}$ Brix.

On the other hand, the value for single-strength peach puree was published by Garza et al. (1999). These authors reported total soluble solids content ( ${ }^{\circ}$ Brix) of $11.1, \mathrm{pH}$ of 3.8 , total acidity (citric acid g/100 mL) of 0.515 , total nitrogen (mg nitrogen/100 $\mathrm{mL}$ ) of 86.45 and fiber (\% weight) of 1.5; the industrial puree was obtained from peaches of different varieties (Sudanell, Babygold, Carson, etc.). In general, the results for Jubileu peach puree at $22{ }^{\circ} \mathrm{Brix}$ were 2 -to 3 -fold higher than those reported by these authors for ${ }^{\circ} \mathrm{Brix}, \mathrm{pH}, \mathrm{TA}$, and fiber.

On the other hand, Greenwood Associates (1974), a company that manufactures concentrated peach puree, reported total soluble solids content ( $\left.{ }^{\circ} \mathrm{Brix}\right)$ of $30-32, \mathrm{pH}$ of 3.7-3.9, total acidity (citric acid $\mathrm{g} / 100 \mathrm{~mL}$ ) of 1.7 , and maximum microbial values of yeast and mold $<100 \mathrm{CFU} \cdot \mathrm{g}^{-1}$. The total initial microbial count of $22 \times 10^{2}$ UFC. $\mathrm{mL}^{-1}$ was obtained in the present study after a long period of storage at $-20^{\circ} \mathrm{C}$. This value is within the limit established by the Brazilian legislation in 2000 (Brasil, 2000).

Table 1. Physical and chemical characteristics of Jubileu peach puree.

\begin{tabular}{cc}
\hline Parameter & Value \\
\hline Total nitrogen (mg nitrogen $/ 100 \mathrm{~mL})$ & 340 \\
Ash (\%) & 0.40 \\
Moisture $(\%)$ & 68 \\
Total fibers $(\%)$ & 4.0 \\
$\mathrm{pH}$ & 22.0 \\
Soluble solids content $\left({ }^{\circ}\right.$ Brix) at $25^{\circ} \mathrm{C}$ & 3.5 \\
Titratable acidity [TA] (g citric acid/100g) & 1.8 \\
Reducing sugars $(\%)$ & 11.0 \\
Residual PPO activity & Not detected \\
Count plates (PDA) & $22 \times 10^{2}$ UFC.mL $\mathrm{mL}^{-1}$ \\
\hline
\end{tabular}




\subsection{Microbial reduction}

Figure 1 shows the heat resistence of the yeast isolated from spoiled peach puree. The initial microbial yeast count was approximately $10^{8} \mathrm{UFC} . \mathrm{mL}^{-1}$. The yeast heat resistence (55-65 ${ }^{\circ} \mathrm{C}$ ) was appropriately described using first-order kinetics. At $65{ }^{\circ} \mathrm{C}, 95 \%$ of the initial microbial yeast count was lost after 40 seconds. Above $58{ }^{\circ} \mathrm{C}$, yeast reduction in the total count increased. Yeast isolated from a high-sugar strawberry product showed similar behavior (Truong-Meyer et al., 1997).

Table 2 shows values of $\mathrm{k}, \mathrm{D}$, and $\mathrm{Z}$ for the yeast isolated from spoiled peach puree and its heat resistance using Mcllvaine buffer at $\mathrm{pH}$ 5. The kinetic constants of the yeast varied from $2.53 \times 10^{-3}$ to $8.61 \times 10^{-2} \mathrm{~s}^{-1}$ in the temperature range of $55-65^{\circ} \mathrm{C}$ and from 15.15 to 0.45 minutes for $\mathrm{D}$ values.

In contrast with the $\mathrm{D}$ values of the peach puree yeast, the results reported by Reveron et al. (2003) in a study on thermal resistance of Saccharomyces cerevisiae in Pilsen beer at $\mathrm{pH} 4.8$, are lower than those obtained in the present study. They reported $\mathrm{D}_{60}$ value of 0.01 minute and $\mathrm{Z}$ value of $4.6^{\circ} \mathrm{C}$. The $\mathrm{D}_{60}$ value obtained in the present study, estimated by the equation of the TDT curve, was of 2.6 minutes, and the Z-value was $6.54{ }^{\circ} \mathrm{C}$ (Table 2). The $\mathrm{Z}$-value is computed from negative inverse of the slope $(m=-0.153)$; see Equation 5 . It was also higher than the $\mathrm{D}_{60}$ values and $\mathrm{Z}$-values of the three yeasts isolated from spoiled peach puree using Mcllvaine buffer at $\mathrm{pH} 4$ and buffer at $\mathrm{pH} 7$ reported by Garza et al. (1994b). No significant differences in

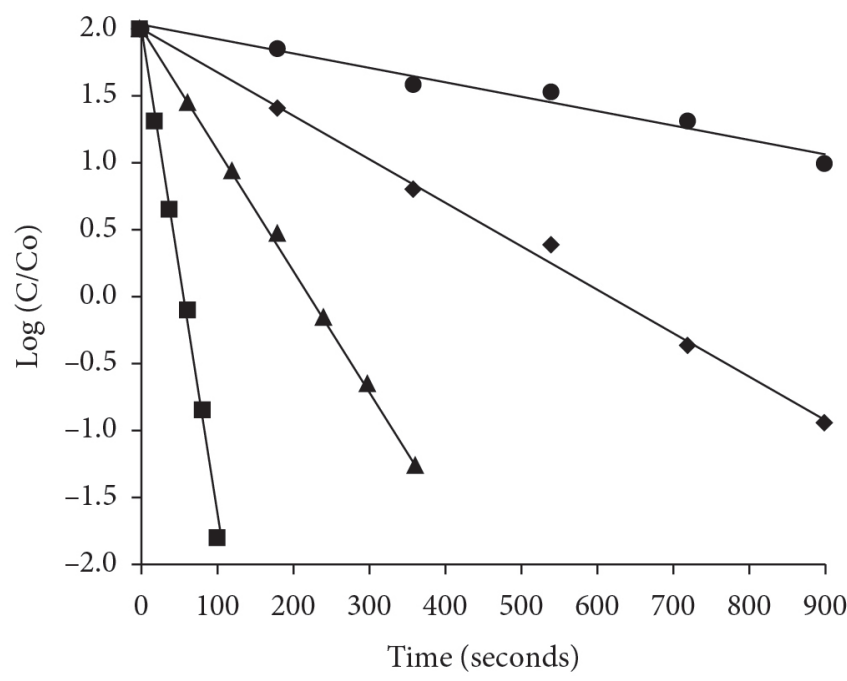

Figure 1. Thermal inactivation of yeast isolated from spoiled peach puree. Yeast extract was heated for the indicated times to $55(\bullet), 58(\bullet)$, $61(\boldsymbol{\Delta})$, and $65^{\circ} \mathrm{C}(\mathbf{\square})$. the $\mathrm{Z}$-value using buffer at $\mathrm{pH} 7$ and $\mathrm{pH} 4$ were observed by these authors probably because the yeasts isolated came from different sources of peach puree and not because of the influence of $\mathrm{pH}$ on the thermal resistance of yeast.

On the other hand, although there is no effect of $\mathrm{pH}$ differences on the thermal resistance of yeast, it was observed that during the counting of yeast and mould in the peach puree at $\mathrm{pH} 3$, fungus colonies prevailed (data not shown). This is the reason why the cultivation and isolation of the peach yeast and fermentation were carried out at $\mathrm{pH}$ 5. According to Beuchat (2005), the optimum $\mathrm{pH}$ for S. cerevisiae growth is between 4 and 5 .

In the thermal processing of fruit puree, yeast cannot be the most important spoilage agent. Carvalho-Filho \& Massaguer (1997) stated that Clostridium butyricum was initially used as target organism for the thermal processing of banana puree. However, its $\mathrm{pH}$ limit of 4.6 favors Clostridium botulinum growth. They found similar Dvalues at $115^{\circ} \mathrm{C}$ for C. butyricum and C. botulinum ( $0.183 \mathrm{~min}$ and $0.236 \mathrm{~min}$, respectively), which are higher than those obtained in the present study.

\subsection{Thermal inactivation of PPO and POD}

Figure 2 shows the remaining Jubileu PPO activity in catechol. The initial PPO activity was $17.8{\mathrm{U} . \mathrm{mg}^{-1}}$ at $\mathrm{pH}$ 6.2, equivalent to $100 \%$ of relative activity (RA). In Figure 2, that value is the same at residual activity $(\log \%)=2$ for zero seconds. From that point on, thermal inactivation of Jubileu PPO showed apparent first-order kinetics, and its residual activity was typically linear between $50-60{ }^{\circ} \mathrm{C}$. In the longest heating times, there is an apparent deviation from linearity. This deviation could indicate the presence of a second enzyme with greater thermal resistance. PPO and POD in Granada clingstone peaches showed this behavior (Toralles et al., 2004). Anthon et al. (2002) also observed such behavior in pectin methyl esterase in tomato juice. At $70{ }^{\circ} \mathrm{C}, 95 \%$ of the PPO activity was lost after 540 seconds, and similar loss was observed after incubation at $90{ }^{\circ} \mathrm{C}$ for about 60 seconds, suggesting that PPO catalytic structure was significantly changed when temperature increased.

Thermal inactivation of POD in guaiacol substrate also showed apparent first-order kinetics (Figure not shown), and the initial POD activity was $15.88 \mathrm{U} / \mathrm{mg}$ at $\mathrm{pH} 5$ (RA of $100 \%$ ). The activity rapidly decreased above $50{ }^{\circ} \mathrm{C}$. At $65{ }^{\circ} \mathrm{C}, 95 \%$ of the activity was lost after 150 seconds. For PPO, similar loss was observed after incubation at $70{ }^{\circ} \mathrm{C}$ for about 540 seconds, suggesting that PPO has higher thermal stability than POD. These results suggest that PPO and POD catalytical structures are significantly changed when temperature increases. This

Table 2. Heat resistance data of the yeast isolated from spoiled Jubileu peach puree.

\begin{tabular}{cccccc}
\hline Heating temperature $\left({ }^{\circ} \mathrm{C}\right)$ & $\mathrm{k}$ value $\left(\mathrm{s}^{-1}\right)$ & $\mathrm{D}$ value $(\mathrm{min})$ & Equation of the TDT curve & $\mathrm{R}^{2}$ & 0.999 \\
\hline 55 & $2.53 \times 10^{-3}$ & 15.15 & & \\
58 & $7.37 \times 10^{-3}$ & 5.21 & $\log \mathrm{D}=-0.153 \mathrm{~T}+9.58$ & & \\
61 & $2.05 \times 10^{-2}$ & 1.87 & & \\
65 & $8.61 \times 10^{-2}$ & 0.45 & & \\
\hline
\end{tabular}


Table 3. Inactivation parameters of Jubileu peach PPO and POD at $60^{\circ} \mathrm{C}$.

\begin{tabular}{cccccccc}
\hline \multirow{2}{*}{ Enzyme } & \multicolumn{5}{c}{ Parameters } \\
\cline { 2 - 7 } & $\mathrm{T}_{\mathrm{ref}}\left({ }^{\circ} \mathrm{C}\right)$ & ${ }^{\mathrm{a}} \mathrm{k}_{\mathrm{ref}}\left(\mathrm{s}^{-1}\right)$ & ${ }^{\mathrm{b}} \mathrm{k}_{\mathrm{obs}}\left(\mathrm{s}^{-1}\right)$ & $\mathrm{D}$-value $(\mathrm{min})$ & $\mathrm{t}_{1 / 2}(\mathrm{~s})$ & ${ }^{\mathrm{c}} \mathrm{Ea}\left(\mathrm{kJ} \cdot \mathrm{mol}^{-1}\right)$ & $\mathrm{R}^{2}$ \\
\hline PPO & 60 & $2.29 \times 10^{-3}$ & $2.22 \times 10^{-3}$ & 17.3 & 312.2 & $111.1 \pm 13.3$ & 0.996 \\
POD & 60 & $1.6 \times 10^{-2}$ & $1.36 \times 10^{-2}$ & 2.4 & 43.1 & $97.2 \pm 20.9$ & 0.976 \\
\hline
\end{tabular}

${ }^{\mathrm{a}} \mathrm{k}_{\mathrm{ref}}$ estimated value for the rate constant for inactivation at reference temperature $\left(\mathrm{T}_{\mathrm{ref}}\right) .{ }^{\mathrm{b}} \mathrm{k}_{\mathrm{obs}=}$ observed value for the rate constant for inactivation at reference temperature $\left(\mathrm{T}_{\text {ref }}\right) .{ }^{\mathrm{c}}$ value \pm confidence interval at $\mathrm{p}=0.05$.

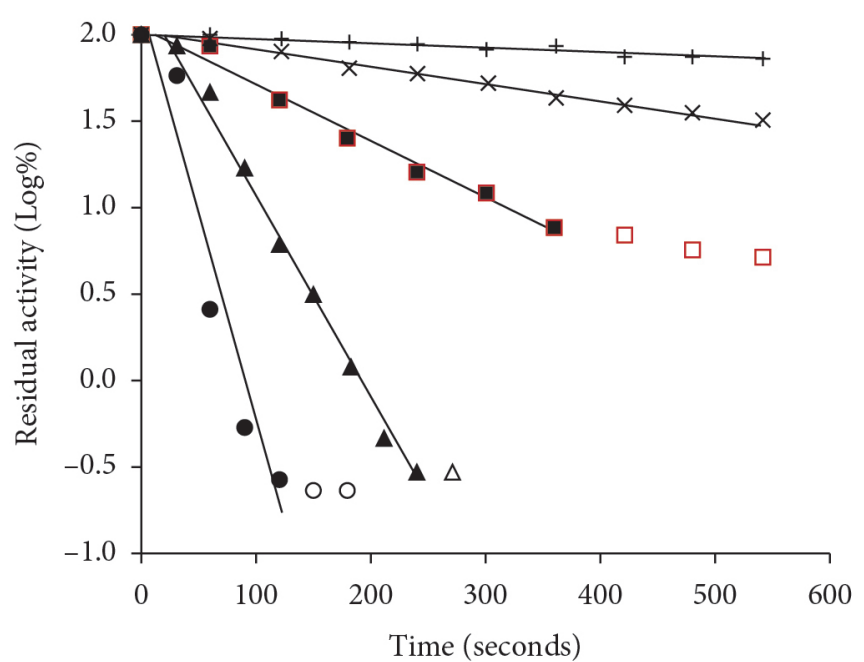

Figure 2. Thermal inactivation of polyphenoloxidase in catechol substrate. PPO extract from Jubileu clingstone peach was heated for the indicated times at $50(+), 60(\times), 70(\boldsymbol{\bullet}), 80(\boldsymbol{\Delta})$, and $90{ }^{\circ} \mathrm{C}(\bullet)$.

probably happens because of the significance of the noncovalent bond in maintaining the structure of enzymes. These bonds involve van der Waals forces, electrostatic interactions, hydrogen bonds, and hydrophobic interactions. When high temperatures disrupt noncovalent interactions, proteins unfold (Vieille \& Zeikus, 2001; Kristjánsson \& Ásgeirsson, 2003). Recent studies indicate that the active site tends to be more flexible than the enzyme as a whole, and that activity losses precede denaturation (Daniel et al., 2010).

Table 3 shows the Arrhenius parameters at $60^{\circ} \mathrm{C}$, half-lives $\left(\mathrm{t}_{1 / 2}\right)$, and activation energies (Ea). The values of the Arrhenius parameters were determined using Equation 2 by linear regression and Equation 3 for half-lives. High coefficients of determination $\left(\mathrm{R}^{2}\right)$ justify the use of the Arrhenius law for both enzymes. PPO half-life $\left(t_{1 / 2}=312.2 \mathrm{~s}\right)$ was higher than that of POD $\left(\mathrm{t}_{1 / 2}=43.1 \mathrm{~s}\right)$. On the other hand, inactivation rate $(\mathrm{k})$ of POD $\left(1.36 \times 10^{-2}\right)$ was higher than that of PPO $\left(2.22 \times 10^{-3}\right)$. Based on the half-life and inactivation rate, it is possible to prove that PPO is kinetically more stable than POD.

In general, $\mathrm{k}_{60}$-values and half-life values obtained for Jubileu peach PPO and POD are higher than those of Granada peach PPO and POD found by Toralles et al. (2005). These authors reported $\mathrm{k}_{60}=3.4 \times 10^{-3} \mathrm{~s}^{-1}$ and $\mathrm{t}_{1 / 2}=214.6 \mathrm{~s}^{-1}$ for PPO, and $\mathrm{k}_{60}=10.9 \times 10^{-3} \mathrm{~s}^{-1}$ and $\mathrm{t}_{1 / 2}=67.2 \mathrm{~s}^{-1}$ for POD. They also revealed that PPO in Granada $\left(\mathrm{Ea}=127.3 \mathrm{~kJ} . \mathrm{mol}^{-1}\right)$ was the least heat stable and POD in Granada $\left(\mathrm{Ea}=147.9 \mathrm{~kJ} \cdot \mathrm{mol}^{-1}\right)$ was the most heat stable. In the present study, considering the confidence interval, the activation energies were of equivalent magnitude.

Fortea et al. (2009), evaluating the activity of PPO and POD in table grape (Crimson Seedless), obtained approximately 2 -fold higher values than those found in the current study for $\mathrm{Ea}$, and similar thermostability for both enzymes, losing $>90 \%$ of relative activity after only $5 \mathrm{~min}$ of incubation at $78^{\circ} \mathrm{C}$ and $75^{\circ} \mathrm{C}$, respectively. In general, higher activation energy implies that a lower temperature change is needed to inactivate an enzyme.

In contrast with the $\mathrm{D}_{60}$ value $(2.6 \mathrm{~min})$ for peach puree yeast, the $\mathrm{D}_{60}$ value $(17.3 \mathrm{~min})$ obtained for Jubileu peach PPO was approximately 7.5 -fold higher than that of yeast. Nonetheless, the D values of POD (2.4 min) and peach puree yeast were similar (Tables 2 and 3). Therefore, Jubileu peach PPO was more thermostable than the POD and yeast. GuerreroBeltrán \& Barbosa-Cánovas (2006), investigating Saccharomyces cerevisiae and $\mathrm{PPO}$ in mango nectar treated with UV light inactivation, also reported that PPO was the most UV-light stable.

A comparative study between Jubileu PPO and Granada PPO inactivation was carried out by a computer simulation using kinetic data. The analysis was performed at $75^{\circ} \mathrm{C}$ and $80^{\circ} \mathrm{C}$; both are typical temperatures used during peach pure processing. At $75{ }^{\circ} \mathrm{C}$, temperature used to blanch the Jubileu peach puree, 3 additional minutes should be added to the treatment proposed by Toralles et al. (2008) for the Granada peach puree at $75^{\circ} \mathrm{C}$ for 4 minutes.

At $80^{\circ} \mathrm{C}$, it is possible to keep the thermal treatment for 4 minutes to blanch the Jubileu peach puree. Since blanching at $75^{\circ} \mathrm{C}$ for 4 minutes is not sufficient to inactivate Jubileu PPO, $0.08 \%$ ascorbic acid had to be added to the puree after blanching. This must have inhibited the PPO activity until its concentration. This operation followed by pasteurization also guaranteed no residual activity in the final product, Jubileu peach puree at $22^{\circ}$ Brix (see Table 1 ).

\section{Conclusion}

PPO and POD of Jubileu clingstone peaches and yeast isolated from spoiled peach puree showed different heat resistances at real blanching and pasteurization temperature. Heat treatments significantly reduced peach PPO and POD activity. Heat denaturation was highly effective above $80^{\circ} \mathrm{C}$ for PPO and above $60^{\circ} \mathrm{C}$ for POD. The thermal stability of PPO was higher than that of POD. In addition, PPO was more thermally stable than the yeast isolated from Jubileu peach puree. The $\mathrm{D}_{60}$ values were 17.3 and $1.87 \mathrm{~min}$ for PPO and yeast isolated from spoiled Jubileu peach puree, respectively. In all cases, 
heat inactivation was described using exponential decay (first order reaction), while the Arrhenius law described temperature dependence of all reactions. Finally, in the continuous blanching, increasing thermal treatment to $80^{\circ} \mathrm{C}$ for 4 minutes is advisable to inactivate Jubileu PPO, and thus it would be an indicator for browning enzyme inactivation in peaches.

\section{Acknowledgements}

Thanks are due to Veronica Gutierres Santana for expert technical assistance and Dr. Pedro Luis Antunes (Posthumous) for the helpful comments on this project conception.

\section{References}

Alba, C. M., De Forchetti, S. M., \& Tigier, H. A. (1996). Peroxidase and phenoloxidase activities in peach endocarp. In C. Obinger, U. Burner, R. Ebermann, C. Penel, \& H. Greppin, (Eds.), Plant Peroxidases: Biochemistry and Physiology (pp. 243-246). University of Geneva.

Anthon, G. E., Sekine, Y., Watanabe, N., \& Barret, D. (2002). Thermal inactivation of pectin methylesterase, polygalacturonase, and peroxidase in tomato juice. Journal of Agricultural and Food Chemistry, 50, 6153-6159. http://dx.doi.org/10.1021/jf020462r

Beuchat, L. R. (2005). Traditional fermented foods. In M. P. Doyle, L. R. Beuchat, \& T. J. Montville (Eds.), Food Microbiology. Fundamentals and Frontiers. (2 ed., pp. 701-720). Washington: ASM Press.

Bi, X., Liu, F., Rao, L., Li, J., Liu, B., Liao, X., \& Wu, J. (2013). Effects of electric field strength and pulse rise time on physicochemical and sensory properties of apple juice by pulsed electric field. Innovative Food Science \& Emerging Technologies, 17, 85-92. http://dx.doi. org/10.1016/j.ifset.2012.10.008

Brasil, Ministério da Agicultura, Pecuária e Abastecimento. (2000). Padrões de Identidade e qualidade para polpas de frutas (Instrução Normativa Normativa $n^{\circ} 1$, de 7 de janeiro de 2000). Diário Oficial da República Federativa do Brasil.

Brito, C. A. K., Sato, H. H., Spironello, A., \& Siqueira, W. J. (2005). Características da atividade da peroxidase de abacaxis Ananascomosus (L.) Merrill) da cultivar IAC gomo-de-mel e do clone IAC-1. Ciência e Tecnologia de Alimentos, 25(2), 244-249. http://dx.doi.org/10.1590/S0101-20612005000200010

Carvalho Filho, C. D., \& Massaguer, P. R. (1997). Processamento térmico de purê de banana (Musa cavendishii, Lamb.) em embalagens flexíveis esterelizáveis. Ciência e Tecnologia de Alimentos, 17(3), 213-218. http://dx.doi.org/10.1590/S0101-20611997000300004

Daniel, R. M., Peterson, M. E., Danson, M. J., Price, N. C., Kelly, S. M., Monk, C. R., Weinberg, C. S., Oudshoorn, M. L., \& Lee, C. K. (2010). The molecular basis of the effect of temperature on enzyme activity. Biochemical journal, 425(2), 353-360. PMid:19849667. http://dx.doi. org/10.1042/BJ20091254

Fazio, M. L. S. (2006). Qualidade microbiológica e ocorrência de leveduras em polpas congeladas de frutas (Dissertação de mestrado). Universidade Estadual Paulista, São José do Rio Preto.

Flurkey, W. H., \& Jen, J. J. (1978). Peroxidase and polyphenoloxidase actives in developing peaches. Journal of Food Science, 43, 18261831. http://dx.doi.org/10.1111/j.1365-2621.1978.tb07424.x

Fortea, M. I., López-Miranda, S., Serrano-Martínez, A., Carreño, J., \& Núñez-Delicado, E. (2009). Kinetic characterisation and thermal inactivation study of polyphenol oxidase and peroxidase from table grape (Crimson Seedless). Food Chemistry, 113(4), 1008-1014. http://dx.doi.org/10.1016/j.foodchem.2008.08.053

Funamoto, Y., Yamauchi, N., Shigyo, M. (2003). Involvement of peroxidase in chlorophyll degradation in stored brocolli (Brassica oleracea L.) and inhibition of the activity by heat treatment. Postharvest Biology and Technology, 28(1), 39-46. http://dx.doi. org/10.1016/S0925-5214(02)00143-6

Garcia, E., \& Barrett, D. M. (2005). Fresh-Cut Fruits.In: S. Barrett \& Ramaswamy (Eds.). Processing fruits: science and technology. (2nd ed., pp. 53-72). New York: CRC Press.

Garza, S., Prio, A., Vinas, P. I., \& Sanchis, V. (1994a). Isolation and identification of spoilage organisms in commercial peach puree. Italian Journal of Food Science, 6(3), 351-355.

Garza, S., Teixido, J. A., Sanchis, V., Vinas, I., \& Condon, S. (1994b). Heat resistance of Saccharomyces cerevisiae strains isolated from spoiled peach puree. International Journal of Food Microbiology, 23(2), 209-213. http://dx.doi.org/10.1016/0168-1605(94)90053-1

Garza, S., Ibarz, A., Pagan, J., \& Giner, J. (1999). Non-enzimatic in peach pure during heating. Food Research International, 32(5), 335-343. http://dx.doi.org/10.1016/S0963-9969(99)00094-0

Girner, J., Ortega, M., Mesegue, M., Gimeno, V., Barbosa-Canovas, G. V., \& Martin, O. (2002). Inactivation of peach polyphenoloxidase by exposure to pulsed electric fields. Journal of Food Science, 67(4), 264-267.

Greenwood Associates. (1974). Fruit Juice Concentrates, purees and essential oils, since 1974. Retrieved from http://www. okyanusbilgiambari.com/Bilim/Okyanus-BrowinginFoods.pdf

Guerrero-Beltrán, J. A., \& Barbosa-Cánovas, G. V. (2006). Inactivation of Saccharomyces cerevisiae and polyphenoloxidase in Mango Nectar Treated with UV Light. Journal of Food Protection, 69(2), 362-368.

Guerrero-Beltrán, J. A., Barbosa-Cánovas, G. V., \& Swanson, B. G. (2004). High hydrostatic pressure processing of peach puree with and without antibrowning agents. Journal of Food Processing and Preservation, 28(1), 68-85. http://dx.doi. org/10.1111/j.1745-4549.2004.tb00538.x

Instituto Adolfo Lutz - IAL. (2008). Métodos físico-químicos para análise de alimentos (4. ed.). São Paulo. Retrieved from http://www. ial.sp.gov.br.

Kristjánsson, M. M., \& Ásgeirsson, B. (2003). Properties of Extremophilic Enzymes and Their Importance in Food Science and Technology. In J. R. Whitaker, A.G. J. Voragen, D. W. S. Wong (Eds.), Handbook of Food Enzymology (pp. 91-114). New York: Marcel Dekker.

Lowry, O. H., Rosebrough, N. J., Farr, A. L., \& Randalll, R. J. (1951). Protein measurement with the Folin phenol reagent. Journal Biological Chemistry, 193, 265-275. PMid:14907713.

McEvily, A. J., Iyengar, R., Otwell, W. S. (1992). Inhibition of enzymatic browning in food and beverages. CRC - Critical Reviews in Food Science and Nutrition, 32(3), 253-273. PMid:1418602. http://dx.doi. org/10.1080/10408399209527599

McLellan, M. R., \& Padilla-Zakour, O. I. (2005). Juice processing. In: S. Barrett \& Ramaswamy (Eds.), Processing fruits: science and technology (2nd ed., pp. 74-94). New York: CRC Press.

Pinto, A. M. A. (2008). Efeito da alta pressão na atividade da enzima peroxidase (Dissertação de Mestrado). Universidade de Aveiro, Aveiro.

Prohens, J., Rodríguez-Burrezo, A., Raigón, M. D., \& Nuez, F. (2007). Total Phenolic Concentration and Browning Susceptibility in a Collection of Different Varietal Types and Hybrids of Eggplant: 
Implications for Breeding for Higher Nutritional Quality and Reduced Browning. Journal of the American Society of Horticultural Science, 132(5), 638-646.

Quevedo, R., Ronceros, B., Garcia, K., Lopéz, P., \& Pedreschi, F. (2011). Enzymatic browning in sliced and puréed avocado: a fractal kinetic study. Journal of Food Engineering, 105(2), 210-215. http://dx.doi. org/10.1016/j.jfoodeng.2011.02.012

Ramírez, E. C., Whitaker, J. R., \& Virador, V. M. (2003). Polyphenol Oxidase. In J. R. Whitaker, A. G. J. Voragen, D. W. S. Wong (Eds.), Handbook of food enzymology, Polyphenol oxidase (pp. 509-523). New York: Marcel Dekker.

Ranieri, A., Castagna, A., Baldan, A., \& Soldatini, G. F. (2001). Iron deficiency differently affects peroxidase isoforms in sunflower. Journal of Experimental Botany, 52(354), 25-35. PMid:11181710. http://dx.doi.org/10.1093/jexbot/52.354.25

Reveron, I. M., Barreiro, J. A., \& Sandoval, A. J. (2003). Thermal resistance of Saccharomyces cerevisiae in Pilsen beer. Journal of the Institute of Brewing, 109(2), 120-122. http://dx.doi. org/10.1002/j.2050-0416.2003.tb00140.x

Reyes, P., \& Luh, B. S. (1960). Characteristics of Browning Enzymes in Fay Elberta Freestone Peaches. Food Technology, 14, 570-575.

Siqueira, R. S. (1995). Manual de microbiologia de alimentos. Rio de Janeiro: Embrapa.

Toralles, R. T., \& Vendruscolo, J. L. (2007). Processamento do purê e néctar de pêssego (Vol. 159, Comunicado Técnico). Pelotas: Embrapa Clima Temperado.

Toralles, R. T., Vendruscolo, J. L., Haas, L. I. R.,; Ferri, N. L., Del Pino, F. A. V., \& Antunes, P. L. (2004). Partial characterization of the enzymatic browning for polyphenoloxidase in peaches of the cv Ganada, Jade, Esmeralda and Maciel. Revista Brasileira de Agrociência, 10(2), 241-244.
Toralles, R. P., Vendruscolo, J. L., Tondo-Vendruscolo, C., Del Pino, F. B, \& Antunes, P. L. (2005). Properties of polyphenoloxidase and peroxidase from Granada clingstone peaches. Brazilian Journal of Food Technology, 8(3), 233-242.

Toralles, R. P., Malgarim, M. B., Vendruscolo, J. L., Cantillano, R. F., \& Treptow, R. O. (2006). Um estudo para compreender a preferência e aceitação de consumidores de purês de pêssegos brasileiros. Revista Brasileira de Fruticultura, 28(3), 397-401. http://dx.doi.org/10.1590/ S0100-29452006000300013

Toralles, R. P., Vendruscolo, J. L., Tondovendruscolo, C., Del Pino, F. B., \& Antunes, P. L. (2008). Determinação das constantes cinéticas de degradação do ácido ascórbico em purê de pêssego. Ciência e Tecnologia dos Alimentos, 28(1), 18-23. http://dx.doi.org/10.1590/ S0101-20612008000100004

Toralles, R. P., Vendruscolo, J. L., Tondo-Vendruscolo, C., Del Pino, F. B., \& Antunes, P. L. (2010). Controle da atividade da polifenoloxidase de pêssego por interação do $\mathrm{pH}$, da temperatura e da concentração de ácido ascórbico. Brazilian Journal of Food Technology, 13(2), 120127. http://dx.doi.org/10.4260/BJFT2010130200016

Truong-Meyer, X., Strehaiano, P., \& Riba, J. (1997). Thermal inactivation of two strains heated in a strawberry product: experimental data and kincect model. Chemical Engineering Journal, 99-104. http:// dx.doi.org/10.1016/S1385-8947(96)03153-1

Valderrama, P., \& Clemente, E. (2004). Isolation and thermostability of peroxidase isoenzymes from apple cultivars Gala and Fuji. Food Chemistry, 87(4), 601-606. http://dx.doi.org/10.1016/j. foodchem.2004.01.014

Vieille, C., \& Zeikus, G. J. (2001). Hyperthermophilic enzymes: sources, uses, and molecular mechanisms for thermostability. Microbiology and Molecular Biology Reviews, 65(1), 1-43. PMid:11238984 PMCid:PMC99017. http://dx.doi.org/10.1128/MMBR.65.1.143.2001 